\title{
Issues in the Theory of Human Capital: Education as Investment
}

\section{FRITZ MACHLUP*}

After a few references to the early literature on human capital, from Petty via Smith, Engel, and Nicholson to Marshall, various issues in current theory of human capital are briefly reviewed. They include questions regarding categories of "tangible human capital" and "intangible nonhuman capital;" investment in raising children, in schooling, and in research and development; depreciation of human capital through obsolescence, loss of strength, illness, retirement, and death; conflicts between efficiency and equality in the educational system; wrong educational mix resulting in waste or even net loss; the problem of complementarity among different kinds of physical and human capital; and the complexity of econometric research on comparative returns to different investments.

\section{INTRODUCTION}

Volume III of my projected ten-volume series on Knowledge: Its Creation, Distribution, and Economic Significance will carry the title The Economics of Information and Human Capital. Part One of this volume deals with the economics of knowledge and information, Part Two with knowledge as human capital. I started the research in the early 1970s and began writing the manuscript in 1977 . It is now complete with some 900 typed pages, organized into 21 chapters. The part on human capital runs to over 300 pages in 10 chapters. But it will take another 18 months, perhaps 24 months, to get into print. Yes, it seems there is no end to making a book. With the prospect of such a long waiting period, I have gladly accepted the invitation of the editor of this learned journal to present some of the things I have learned.

\section{The Early Literature on Human Capital}

Let me begin with an attempt to dispel the misconception that the theory of human capital is an entirely new field in economics. Many young students actually believe that the economics of human capital has developed quite recently, beginning in the 1950 s or 1960 s. This impression has arisen probably because of the work of

* Prof

*Professor Machlup is currently Professor Emeritus at Princeton University and also Professor of Economics at New York University. This article is based on the lecture on "The Theory of Human Capital" that Professor Machlup delivered in a Seminar organized by the Pakistan Institute of Development Economics (PIDE) at Islamabad on November 21, 1981. "The full proceedings of the Seminar have been published separately by the PIDE in its new "Lectures in Development Economics" series. 
two economists who, in the late 1950s, put the notion of human capital on the map, prominent for everyone to see. They actually revived a venerable idea, showed its significance for the explanation of currently observed phenomena, and their presentation was forceful and rigorous. These two men deserve our respect and admiration. Fortunately, our profession has not failed to recognize their achievement. They are Theodore Schultz [21;22] and Gary Becker [1;2], both of the University of Chicago. Their work in this area of analysis and research has induced many other economists to enter this field and develop it further.

Schultz applied the notion of human capital to the economics of education, particularly to an explanation of the increase in productivity of human resources; he also examined the relationship between human capital and economic growth. Gary Becker engaged in more technical research in mathematical and statistical economics He undertook to compute rates of return to the investments people have made in their own skills and efficiency - in self-improvement - chiefly through schooling and training. That Schultz and Becker were not the first economists to show the role of human capital does not reduce the magnitude of their achievement.

The first estimate of a nation's stock of human capital was probably made around 1676 by Sir William Petty for his Political Arithmetick (published posthumously in 1690) [19]. Petty did not, however, use his estimate in support of any substantive hypotheses or in connection with any theoretical model for the derivation of causal connections.

Exactly a hundred years later, in 1776, Adam Smith published his Inquiry into the Nature and Causes of the Wealth of Nations [23]. Smith was quite clear about the role of human capital. In his discussion of the nation's "stock," he remarked on most people's preconception of the capital stock as always being something physical, such as factories, machines, or tools; and he warned the reader not to forget that one of the important parts of capital stock is the raised productivity of human beings. Smith considered education as one of the effective ways of increasing the productivity of human resources. That Smith was highly critical of the quality of teaching at Oxford University and of the counterproductive arrangements in the university education of his time should not be mistaken as an argument against capital formation through education. He emphasized the development of skills through specific kinds of training.

In 1883, a German statistician by the name of Ernst Engel published a book on the "Cost Value of Human Beings" [7]. (Lest you confuse this Engel with Friedrich Engels, the collaborator of Karl Marx, let me assure you that they are neither identical nor related.) Ernst Engel planned two volumes on Der Wert des Menschen but finished only Volume I, treating the investment outlays made for man as productive factor; he was chiefly concerned with the cost of food invested in the growing child. (This conception has recently been revived by John Kendrick, an attempt to which I shall later return.)
In this brief intellectual history I must not leave out the English economist Joseph Nicholson. He published an article in 1891 on "The Living Capital of the United Kingdom" [18]. He was quite explicit regarding the fact that he was dealing with an old notion. He said that "almost all systematic writers on Political Economy have discussed the question whether or not the skill of the artisan, . . , and other intangible elements of the social fabric should be included in the wealth of the in dividual or the nation." Nicholson looked to the cost of educating, not the cost of feeding the child, as the major investment in human productivity. Assessing the human capital accumulated in the people of the United Kingdom, he estimated that the total value of the country's "living capital" was more than five times the stock of "dead," that is, physical capital.

Alfred Marshall [17] also should be cited for his clear vision of these ideas. He distinguished "personal" capital from "material" capital; he considered personal capital as being chiefly formed through investment by parents paying and caring for the education of their children.

Coming to the twentieth century, I want to refer to an article by John Raymond Walsh, published in 1935, entitled "Capital Concept Applied to Man" [24]. In 1945 we were given the pioneering study by Milton Friedman and Simon Kuznets on Income from Independent Professional Practice [8]. This book undertook an elaborate empirical test of the thesis that investment in scarce skills was paying off.

My list of early contributions to our topic is surely not complete, but it suffices to show that the theory of human capital had been in the economic and statistical literature for almost 300 years before the floodgates were opened by Schultz [21;22] and Becker $[1 ; 2]$.

\section{Concepts of Capital}

Writing about human capital I must not dodge the issue of the semantics of the word "capital". Many textbooks circumscribe the meaning of the word rather narrowly, confining it to "produced producers' goods." Thus, the concept is not extended to intangibles and not extended to consumer durables. The stress is on physical goods that were "produced," that is, not provided by nature (like land, mineral deposits, or other natural resources).

Other writers, however, have found it useful to widen the meaning of capital in several respects. One extension relates to the users of capital: the use is no longer restricted to producers making other goods but is extended to consumers deriving from it a long-enduring flow of intangible services. To comprehend this, one merely has to think of residential housing. Most national-income statisticians include the construction of residential homes in capital formation. Capital is thus no longer a physical intermediate product used in the production of other physical products, but a durable structure that provides a flow of intangible consumer benefits. Economic theorists have gone beyond economic statisticians in that they include in the capital 
stock all sorts of durable consumer goods, such as automobiles, home appliances, musical instruments, etc. Still, although the future benefits may be intangible, the assets in the capital stock are physical, "tangible."

Coming now to human resources, we find that the capital concept is no longer restricted to tangible assets yielding tangible or intangible services, but extends to intangible assets yielding tangible or intangible services. Still another distinction is to be made with regard to human resources, namely, whether the capital concept should be restricted to investments in improvements of the human resource as a productive factor or whether the human resource should be regarded as capital no matter whether any special outlay has been made to increase its productivity. Economists have sometimes been critical of the strange "fallacy" of regarding the birth of a lamb as an increase in wealth, but the birth of a human child as no such increase but, instead, as a burden, as a reduction of income per head of population. If the newly born child is not seen as an addition to wealth and capital, then at least the investments in feeding and caring for the future workers should, in the view of these economists, be treated as capital formation. Counter arguments, however, point to the possible absence of complementary capital goods, especially in countries suffering from overpopulation.

\section{Investment in Education}

Education is commonly regarded as the major form of investment in human resources. There is the question whether one should consider all outlays for education as formation of human capital regardless of whether the particular teaching and learning would increase the productivity of labour. Education can, by elevating the learners' intellect, improve their quality of life; but it may also improve the individuals' skills and efficiency in producing useful things. Some economists see an important difference between the contribution that education may make to the flow of intangible satisfactions to the educated themselves (and their friends and contemporaries) and the contributions which the skilled and efficient workers will make by producing material goods in greater quantity or of better quality.

We find here again the problem discussed earlier in relation to durable goods: they may contribute to a larger flow of tangible goods or they may induce a larger flow of intangible services yielding psychic satisfaction, but no measurable increase in production. In other words, we face again the problem of distinguishing productive capital from consumption capital. Some economists prefer to treat durable consumption goods as wealth but not as capital. National-income accountants have decided against treating the sources of intangible flows of consumer satisfaction as capital. Other economists, however, do not recognize this as a significant difference, and they treat both kinds of "sources of benefits" as capital; they do not care whether the derived services are used for production or only for consumption.

\section{Types of Investment Opportunities}

Let us try to make this discussion somewhat more concrete, with regard to both physical and human capital. Assume a country has a certain flow of investible funds available. The people of that country - either private owners and borrowers of investible funds or the government - have a variety of investment opportunities. Let us single out four types of potential investments: (1) Physical producers' goods, such as machines and factories, (2) physical durable consumers' goods, such as washing machines and residential houses, (3) schools and teachers to provide vocational skills, (4) schools and teachers to provide knowledge of literature and dance. All four types of investment may yield future flows of benefits that will improve the human condition. Thus, they can all be regarded as capital formation in the wide sense of the term. Still, it may serve an analytic purpose to distinguish subgroups of capital. The investments mentioned under Nos. (1) and (3) may be characterized as productive in that they will increase the efficiency of the nation's productive factors employed to produce a larger output of real goods. In contradistinction, the investments mentioned under Nos. (2) and (4) may be characterized not as inputs in the productive process but as making the lives of people in the future more pleasant or more interesting. For example, using a washing machine is easier than washing by hand; living in a better house is more pleasant than living in sordid and overcrowded quarters; knowing the literary masterpieces of the past and understanding the rites of classical dance may lift people's spirits and add to the enjoyment of their lives.

These differences between production capital and consumption capital are no longer popular among economists. Many economists these days distrust the speculations behind the distinctions. Statisticians treat the four types of investment in a rather non-philosophical way. They would take the costs of the machines, the factories, and also of residential construction and call all of it capital formation. They would eliminate the washing machines from investment outlays and include them in consumption. And the official government statisticians would omit all formation of human capital and, instead, would treat the expenditures for education as current consumption.

Some academic statisticians oppose these operational decisions and make an effort to report investments in human capital. Even there, however, we find a certain inconsistency with regard to current investment and the future flow of benefits. In the case of physical capital goods, such as machines and factories, these items are included in the annual statistic of national product, and their future contributions to the flow of goods and services will appear again in the statistics of national product when the products are eventually sold. In the case of human capital, such as outlays for schooling, these items are included (though only by the idiosyncratic-academic statisticians) in the statistic of national product in the year of investment, but the subsequent flows of benefits from these investments will remain unrecorded in later 
years except if they are giving rise to monetary transactions between sellers and purchasers. This is similar to the way in which in many countries, the services from owner-occupied residential housing remain unreported and unrecorded. While the construction of houses is included as capital formation, and while rentals paid in the future by tenants to landlords will figure in national income, the rental values of owner-occupied houses are disregarded. You can see that we all have great trouble getting our act together.

\section{Investment in Research and Development}

The situation becomes much worse when we proceed to the economists' treatment of outlays for research and development. Although everybody these days is convinced that such outlays are investments - even very good investments the official statisticians have not yet decided in favour of a consistent treatment. Most of the official statistics record outlays for $\mathrm{R}$ and $\mathrm{D}$ as part of the national income (though not as part of capital formation) when the outlays are financed by government agencies or private research organizations. On the other hand, if the outlays for $\mathrm{R}$ and $\mathrm{D}$ are made by private industry, these outlays are not treated explicitly as items in the national product and, still less, as capital formation. Instead, they are treated as current cost of producing whatever the industries concerned are making and selling in the market. Thus, if business firms produce and sell soap, or medicines, or automobiles, their outlays for $\mathrm{R}$ and $\mathrm{D}$ are regarded as part of the cost of current production of soap, or medicines, or automobiles - not as investment or formation of intangible capital $[15 ; 16]$.

Some academic statisticians protest against this inconsistency and prepare and publish modified compilations of the national product in which the outlays for $\mathrm{R}$ and $\mathrm{D}$ are shown as capital formation regardless of who pays for them and whether or not any future benefits from them can be expected with confidence. To state this is not to make an implied criticism; statisticians cannot possibly judge the value of current research findings or of inventions, just as they cannot judge whether the machines and factories that are generally treated as capital formation will turn out to be efficient or worthless.

\section{Four Categories of Capital}

One of the most challenging and disappointing tasks of economists is to find statistical or other operational proxies for their theoretical counterparts, that is, for the mental constructs of which theories are made. I want to refer to the ambitious economist who has recently tried to compute and compile data on the formation and stocks of "total" capital [12]. John W. Kendrick distinguished four categories of annual capital formation and of accumulated capital stocks: (A) non-human tangibles, (B) human tangibles, (C) non-human intangibles, (D) human intangibles
[12]. To characterize the four categories, I shall mention some characteristic items for each: (A) Outlays for construction, machinery and inventory are investments in tangible non-human capital; (B) Outlays for rearing children to working age are investments in tangible human capital; (C) Outlays for research and development are investments in intangible non-human capital; and (D) Outlays for education, training, health, safety, and mobility of people are investments in intangible human capital. One cannot help being impressed by the neat symmetry of this arrangement, though one may take exception to category B, tangible human capital represented by children from age 0 to 14 or 15 . Undoubtedly, parents may derive much pleasure from their children and, hence, a psychic return on their investment in feeding them and caring for them; and in many countries parents may look to their children as a source of income in later years, perhaps their only support in old age. From the point of view of the economy as a whole, however, excessive increases in the population may reduce the productivity of labour.

One may wonder how Kendrick obtained his figures for the statistics of the four categories of capital formation and capital stock in the United States. For some of his series he had to make rather heroic assumptions. For example, for category $\mathrm{C}$, the capital embodying the results of research and development, he started the accumulation with the earliest date for which reliable estimates of outlays were available. This can perhaps be justified by the fact that he produced figures for the stock existing in 1976; if the earliest statistic of R and D expenditures is for 1929, one may argue that in the meantime normal depreciation has reduced the earliest recorded outlays to almost zero.

\section{Depreciation of Human Capital}

This brings us to the question of depreciation. In general, depreciation may be subdivided into deterioration, depletion, and obsolescence. Kendrick does not, however, get too deeply involved in the economics of these reductions in the value of accumulated human capital. Instead, for his statistical series he is satisfied with the use of rules of thumb for acceptable rates of annual depreciation. As economic theorists we would have to engage in more painstaking analyses. We would have to realize that investment in the workers' training-on-the-job depreciates in different ways and at different rates where the depreciation is due to obsolescence of acquired skills, to the loss of the workers' physical and mental strength, to changing rules of their retirement from active service, and so forth. I have attempted some of these analyses, but I shall not report here about the many subtle arguments. If I were asked whether these exercises, analytic or statistical, serve any practical purposes, I would have to reply with a shrug of my shoulders. In economic research, as in basic research in other disciplines, it is best not to ask for immediate usefulness. It is enough that the researcher has found his work interesting and that also some of his readers have been interested. If any hard-nosed pragmatists should question the 
value of such research work we could invite them to deduct some or all of its cost from the total investment in human capital.

\section{Four Outcomes of Schooling}

One may disagree with the view that education is always an investment, and a good investment, for the future, though any such judgments are always questionable. They may sometimes be specious in that one may easily confuse the look forward, the anticipation, with the look backward, the retrospect or afterthought. Perhaps, a little superficially, one may say that most of the cost of schooling is unquestionably investment, but that some is consumption, some is waste, and some may be a real drag, worse than waste [14]. Let me explain these four possible outcomes.

There are surely some parts of the usual school activities that contribute nothing to the future, neither to future flows of psychic satisfactions (cognitive or emotional) nor to future efficiency (in production and in earning an income). Thus, these portions of the cost of schooling are not investment, but they may be current consumption. One would regard them as consumption if they give pleasure. Such pleasures may be the immediate satisfaction derived from learning, from stories, from playing, from enjoying games, talks, friendships. But not only the pupils may derive immediate satisfaction; their mothers may appreciate being temporarily relieved from the responsibilities of supervising their children; to have the children away from home in the care of teacher-babysitters is a boon to many a mother. Neighbours, too, may be among the beneficiaries of the school system: they often appreciate not being bothered by the noisy activities of children on the streets. In my statistical work I have not tried to estimate the values of any of such immediate satisfactions which the school system may give to the learners, their families, or their neighbours. Yet, we should not completely disregard the possibility of regarding a part of the cost of schooling as consumption, particularly since in conventional national-income statistics all of it is treated as consumption.

I have said that parts of the cost of schooling could be waste; such a judgment would be reserved for such parts that are neither investment nor current consumption. In other words, where school education yields neither present nor future benefits, it is waste. But it could be worse than waste, namely, if it not only did not please or help anyone now or later but actually harmed some. Harm to the schooled ones and harm to the nation could come from an educational system that turned out people unfit for work wanted by the community. Sir Arthur Lewis, the great scholar in the field of economic development, has given examples of countries where secondary and tertiary schools have produced unwanted knowledge and worthless skills unwanted and worthless because of the excessive numbers of "overqualified" seekers of employment [13]. Not that overqualified workers would necessarily be unfit to do less qualified work, but often they are unwilling to accept employment in occupations below the social status and below the income level they have come to expect.
In other words, the educational system may have mismatched the preferences and the opportunities of those who have completed their studies. Most societies need lawyers and linguists, historians and literary critics, but not in unlimited numbers. A society not much above the subsistence level needs only very few of these types. If the educational system produces too many of them and they refuse to till the soil or do unskilled manual labour, a reserve army of people without jobs will crowd the towns and cities. Education that reduces the employability of people and, in effect, reduces the productivity of labour becomes a drag to economic development.

Incidentally, what I have just said about educating too many for occupations for which there is not enough demand, holds not only for literary criticism, law, and other high-prestige occupations but also for the most practical occupations in manual work. We need carpenters, plumbers, and electricians, but not millions of them. We need barbers but it would be crazy to train too many people to be skilled barbers; to educate everybody in the art of cutting hair and trimming beards would surely not be formation of human capital. I shall return later to the question of the right and wrong educational mix that is essential to the problem of the contribution of education to economic productivity and growth.

The difference between waste and drag should be clear: if we train a million lawyers who then, because no more lawyers are needed, work as taxi drivers, stree cleaners, or in road-repair crews, the cost of their education is waste; but if they find such menial work demeaning and refuse to do it, their education is worse than waste "Wrong" education may fail to improve productivity and thus be wasteful; or it may contribute to unemployment and thus be harmful. Perhaps I have overemphasized these possibilities, but my purpose has been merely to clarify an issue that is often misunderstood.

\section{Efficiency and Equality}

Having explained why too much schooling may be wasteful, I should also mention that too little schooling may be wasteful. Some investigators - psychologists and educationists - tell us that schooling, to have a positive effect, ought to go on for at least four or five years; that one or two years of schooling does little or nothing for the child. Yet, some countries are so poor that they cannot afford giving four or five years of schooling to all their children. In a very poor country in the Caribbeans, only 16 out of 100 pupils finishing the first year of school have contin ued for a second year, and only 10 went to third grade. Even in some middle income countries in Latin America, no more than 15 percent of children attending first grade stayed in school through the sixth grade [10].

We cannot be sure, of course, that schooling for no more than one or two years is absolutely wasted; some educationists believe it is better than no schooling at all. 
If it is true that it is almost worthless, but that four or more years of school would be very beneficial, then a serious problem of equity and justice may arise: how to allocate exceedingly scarce funds for education. Assume a country could not possibly afford allocating more than $\mathrm{x}$ percent of its total income to schooling its children and that this allocation would allow to give one year of school to all children, or two years to one-half the children, or four years to one-fourth of them, or six years to one-sixth. If additional years of schoolding yield (in this range) more than proportionally increasing benefits, what can one say about the best social choice among these options? Equality of educational opportunity may be sheer waste under the assumed "educational production function." If four years of school produces enormous increments of productive capabilities compared with only two ears of school, should society trade off more social justice to secure much more real national product?

If you are convinced that total product will increase substantially thanks to the availability of people with four years of schooling, will you recommend to the community (the tribe, the nation) that one-fourth of the children be selected for admission to school, and the other three-fourths remain unschooled? I do not know whether your decision becomes more difficult or less as the proportion of educationally underprivileged increases: you may find it more tolerable to educate a very small fraction of the population for positions of leadership, assuming that competent leadership can be of prime importance for increasing the health and wealth of the nation. I am glad that I do not have to make decisions about such conflicts between efficiency and equality. Most economists avoid the problem by rejecting the assumptions, by simply denying that they can be "true" or "relevant" in the real world. That's a cheap way out of a bad dilemma.

The ethical problem of optimal allocation of funds available for the improvement of human resources reminds me of a remark by Sir Dennis Robertson, one of the greatest economists of this century. He said that one of the most important functions of economics is to enable us to find out how expensive social justice and equity is in given circumstances. The cost may be higher than a society can afford. Robertson did not tell us how to decide in a conflict between efficiency and equity; he merely pointed to the need of considering the trade-off, the efficiency-cost of equity. Too often idealists insist on their ideas of social justice, usually egalitarianism, no matter what it costs. The idealists in one country may be satisfied with two years of schooling for all; in another country they are satisfied with no less than sixteen years for all.

\section{Rates of Return to Additional Years of Education}

Research on the question of how differences in annual incomes are statistically associated with differences in school years completed has occupied hundreds of economists in the last twenty-five years. Because of a lack of pertinent data, for most investigations a year of school became the unit of measurement without regard to the type of school and the subjects taught. Only in exceptional instances was it possible to distinguish among different curricula, but the price to pay for such additional information was often that the samples became smaller and therefore less representative. Still, with all faults - bad data, inappropriate samples, and biased specifications in the computations - some of the findings are suggestive of interesting facts and developments. Many of the attempts to compute rates of return to educational investment have yielded unexpected and seemingly inconsistent results, but even apparent errors and fallacies may be helpful in the task of designing more conclusive research projects.

Research in some developing countries in Latin America has led to quite conspicuous differences in computed rates of return to different kinds and lengths of schooling. For example, the highest rate of return was found for young women who had studied to become secretaries. The incremental investment was modest: language skills, typing, and short-hand. These skills are in high demand: foreign and domestic business firms need and look for schooled and trained secretaries; these women were then earning relatively high salaries, making for high rates of return to the investment.

Desperately low rates of return have been calculated for university education in the same countries. A serious flaw, however, may mar these findings: the data for the earnings of university graduates usually exclude the earnings of those who had left the country and were working abroad. Faced with poor job opportunities at home, some of the best graduates have obtained employment in a foreign country, probably at rates of earnings that made for high rates of return on their private investment. The social rate of return on the educational investment may still be very low in that public funds have subsidized the schooling of the emigrees. Even this consideration may be offset by the thought that the emigrees may send parts of their foreign earnings back home to their families. This may not compensate the government for the subsidies and stipends granted, but "society" includes also the relatives of the graduates, and the remittances received from abroad are part of the social gross benefits.

Informative studies have been published on comparative rates of return to material and human capital in India. Mark Blaug and his associates [5] found for the year 1961 that the social rates of return were 13.7 percent on primary education, 12.4 percent on secondary education, and only 7.4 percent on college education; even compared with illiterates, the social rate of return on the investment in college graduates was only 12.3 percent. $^{1}$ On the other hand, rates of return on investment in physical capital ranged from 17 to 26 percent, according to a study by Arnold Harberger [9]. The low returns to human capital in India are in large parts due to 
the mismatch of aptitudes and attitudes of graduates, on the one hand, and job opportunities, on the other.

\section{The Wrong Educational Mix}

Education is not a homogeneous good, neither as an output nor as an input in other production processes. Much depends on whom you educate and how, in what kinds of knowledge or skill, at what levels, for how long, etc., and much depends also on the state of the economy in which the educated plan to work and earn a living. A rich society may have ample demand for art critics, securities analysts, and psychoanalysts, specialists not much in demand in a poor country.

If a poor country copies the educational system of a rich, the likelihood is great that it produces a wrong educational mix, especially at the university level. It cannot be a profitable investment for India, for example, to educate hundreds of thousands of historians, literary critics, and lawyers. Personally, I am a lover of humanistic studies, especially the classical humanities and philosophy, but if I am asked whether I would regard such studies as good investments for a poor developing country, I cannot in good conscience answer affirmatively. Yet, the percentage of students being prepared for practically useful occupations has been relatively small in Indian universities. If high rates of pecuniary returns are being sought, enrollments in schools of technology, engineering, business, and management have been too small relative to enrollments in studies suitable only for richer societies.

Educational policies in some other countries have been quite different. We are told, for example, that in Czechoslovakia over 60 percent of the students in institutions of higher education are in technological, physical, and mathematical sciences. Perhaps there is a terrible loss in this relative neglect of the humanities with their emphasis on values and history, a loss that may adversely affect the spiritual and intellectual development of the nation. But, viewed as an investment in the material productivity of human resources, the emphasis on technology may pay off through a faster rate of economic growth.

In any case, it is not education per se and, still less, schooling as such, that will pay off in the future, regardless of what abilities and attitudes it succeeds in developing. A positive return can be expected only from the improvement of human capacities that are effected by our educational efforts.

\section{Complementarity}

Some teachers have modeled the role of physical capital in the production process by imagining a universal tool or machine that can do everything in every technological process. Helpful as such a model may be for the comprehension of some economic relationships, it may be a hindrance in making the students grasp other economic relationships. The imaginary universal tool allows us to dodge the problem of complementarity of different capital goods: generators, motors, turbines, transmissions, transformers, boilers, tubes, pipes, cables, drills, hammers, screws, nails, and thousands of other hardware, tools, appliances, instruments, machines have to be available in required proportions. It would not do to have generators but no motors, hammers but no nails, electric power but no cables, and so forth.

Similar conditions exist concerning the stock of human capital. It is true that human resources are less "specific" than physical ones. Some people may be good in work of every sort, or they can quickly learn to be good in whatever is demanded in manual or mental labour. By and large, however, people are specialized or, at least, relatively more suitable for some kind of work than for another. The stock of human capital, embodying the learning and training of people, accumulated over short and long periods of time, is composed of many different types of abilities and skills. In view of the existing complementarities, the stock can be valuable - that is, can yield high returns - only if the different forms of human capital are available in proportions that match the technological or organizational requirement of the place and the time. And, as times change, requirements are likely to change.

Complementarity exists also between physical and human capital. The best farm machines will do little good if there are no mechanics to maintain them, to keep them in good repair. Skilled electricians will do little good where there is no electricity. Tailors need fabrics, needles, and thread in order to be useful. Computer centres need hardware, the computers, and software, the programmes provided by programmers. Enough of such examples, the message is clear. There is need for a complex matching of different forms of physical capital and different forms of human capital. The question is who will do the matching and how.

I do not believe that a central board of official "matchers" or planners can do a decent job of it. The free-market system, anonymously coordinating the decentralized self-matchers and professional small-scale matchmakers, operates with many errors and mistakes but still far more efficiently than a central "human-resourcesplanning commission." No central brain (or team of brains) can be trusted with the task of predicting and providing for the right number of engineers, physicists, chemists, medical doctors, statisticians, plumbers, house painters, electricians, mechanics, and so on, and so forth. A market system with flexible wage rates and flexible prices - raising the earnings of workers with scarce skills and increasing the profits of producers of scarce goods, and lowering the earnings of workers with low or abundant skills and eliminating the profits of producers of bad or abundant goods - can provide guidance for reasonably efficient self-channelling of resources into the uses demanded by the people. I know that this casual remark will not sit well with some of my readers. But I speak my mind even if it should make me unpopular.

The essential moral of my discussion of complementarity is that outlays intended to create human capital will in fact prove to have done so only if they result in the right mixture of human aptitudes and attitudes formed through the 
educational effort. And what is right or wrong in this context is not a matter of value judgments but will depend on conditions beyond the control of individuals, groups, cartels, commissions, legislatures, and governments.

\section{Statistical and Econometric Research on Human Capital}

Although I ought to come quickly to the end of this paper, I should not leave unmentioned the large output of statistical and econometric research on problems of human capital or, more correctly, on the question of the contributions that schooling, job training, and perhaps other efforts to improve the efficiency of labour have made to earnings from labour. Primitive attempts to establish correlations between earnings and length of school enrollment were soon rejected in favour of regression analysis, factor analysis, or path analysis, recognizing that more than one single independent variable - the number of school years completed - was needed for a satisfactory "explanation" of differences in the earnings of different groups.

I have devoted a long chapter in my still unpublished book to a survey of educational production functions. In a "parade of variables and models" I show the great variety of ways chosen by different investigators to estimate the effects of schooling, learning, and nonschool training upon earnings from work. Among the more widely used "personal variables" are early intelligence (measured by intelligence quotients before schools), ambition (measured by grades received in early school years), skin colour, region of upbringing (urban, rural, region in the country), region of present residence, hours of work, and'years of job experience; among "family variables" are father's education, father's occupation, mother's education, number of siblings; but some investigators have added "social-psychological variables," such as "friends' plans for college." Some models include the quality of the school (measured by its budget per student); others include more personal factors, such as health (length of illness) and marital status of the individual earner.

Very complex relations are modeled in systems of simultaneous equations, some in sets of recursive regression equations, representing a sequence of production functions for intermediate products where each may include the same input variable that joins with other factors in determining the output at two or more intermediate stages and perhaps also the ultimate product, that is, "earnings." Earnings usually are annual earnings from labour after elimination of incomes from other sources; in a few studies, however, hourly earnings are regarded as the product of the educational production function.

The most delicate issue in this sort of research is the separation of ability and education in determining differences in earnings. The two variables certainly interact, ability increases the effects of schooling, and schooling increases ability. To use sequential tests of ability can attenuate but not eliminate the controversy between those who place more weight on native ability and those who prefer to attribute all ability to environmental influences (milieu). Ability at age zero is not measurable and, in a sense, the entire increment of ability after birth is "acquired." Nonetheless, the effect of IQ on earnings seems to increase over time; that is to say, that school experience and work experience seem to contribute to earnings larger increments for earners who have started life, or at least school, with a higher IQ.

These remarks of mine will again be unpopular with some of my readers, because the opponents of the concept of "genotypic intelligence" are very zealous in fighting for their position. Let me admit that I do not know how this controversy can be decided. I share this ignorance with all others who have written about the subject.

\section{An Apology}

I realize that $\mathrm{I}$ have offered in this paper only a few meagre scraps from my work on the theory of human capital. I have tried to select some issues that I thought may interest the readers of this Review. If I have not succeeded in making good choices, I may say in defence against such a charge that choosing becomes more difficult if the pool of possible choices is very large. I cannot even contend that what I have chosen for presentation in this paper is a representative sample of the contents of my forthcoming book. I hope that the readers of this article will deem it worth while to test this question when the book eventually appears.

\section{REFERENCES}

1. Becker, Gary S. Human Capital. New York: Columbia University Press. 1964.

2. Becker, Gary S. "Investment in Human Capital: A Theoretical Analysis". Journal of Political Economy. Vol. 70. Supplement, October 1962. pp. 9-49.

3. Blaug, Mark. The Economics of Education: An Annotated Bibliography. Third Edition. Oxford: Pregamon Press. 1976.

4. Blaug, Mark. "The Empirical Status of Human Capital Theory: A Slightly Jaundiced Survey". Journal of Economic Literature. Vol. 14. September 1976. pp. 827-855.

5. Blaug, Mark, Richard Layard and Maureen Woodhall. The Causes of Graduate Unemployment in India. London: Allen Lane, Penguin Press. 1969. Table 10.1.

6. Deane, Phyllis. "Petty, William". International Encyclopedia of the Social Sciences. Vol. 12. New York: The Macmillan Company \& The Free Press. 1968.

7. Engel, Ernst. Der Kostenwerth des Menschen (Vol. 1 of a planned series on Der Werth des Menschen). Berlin: L. Simon. 1883. 
8. Friedman, Milton, and Simon Kuznets. Income from Independent Professionai Practice. New York: National Bureau of Economic Research. 1945.

9. Harberger, Arnold C. "Investment in Men versus Investment in Machines: The Case of India". In C. Arnold Anderson and Mary Jean Bowman (eds.), Education and Economic Development. Chicago: Aldine. 1965.

10. Harbison, Frederick, and Charles A. Myers. Education, Manpower and Economic Growth. New York: McGraw-Hill. 1964. p. 110.

11. Hull, Charles H. (ed.). The Economic Writings of Sir William Petty. Vol. 1. Cambridge: University Press. 1899. (Also, New York: Kelley. 1963). pp. 233-313.

12. Kendrick, John W. The Formation and Stocks of Total Capital. New York: National Bureau of Economic Research. 1976.

13. Lewis, W. Arthur. "Education and Economic Development". Social and Economic Studies (Jamaica). Vol. 10. 1961. (Reprinted in Mary Jean Bowman et al. (eds.), Readings in the Economics of Education. Paris: UNESCO. 1968.

14. Machlup, Fritz. Education and Economic Growth. Lincoln, Nebraska: University of Nebraska Press. 1970. (Reprinted, New York: New York University Press. 1975. pp. 21-27.

15. Machlup, Fritz. Knowledge: Its Creation, Distribution, and Economic Significance. Vol. 1, Knowledge and Knowledge Production. Princeton: Princeton University Press. 1980. pp. 193-200; 238.

16. Machlup, Fritz. The Production and Distribution of Knowledge in the United States. Princeton: Princeton University Press. 1962. pp. 184-187.

17. Marshall, Alfred. Principles of Economics. London: Macmillan. 1890 (1st edition); 1920 (8th edition). Book VI, Ch. IV, § 2, 3 and 4 (pp. 560-566); Chapter XI, § 1 (pp. 660-661) and Chapter XII, § 9 (pp. 681-684).

18. Nicholson, Joseph S. "The Living Capital of the United Kingdom". Economic Journal. Vol. 1. March 1891. pp. 95-107.

19. Petty, Sir William. Political Arithmetick. This work was written in or around 1676 , and "first published surreptitiously in 1683 as 'England's Guide to Industry.' . . . The first authorized edition was published posthumously in 1690 by Petty's son." See Phyllis Deane [6, p. 67]. It is also reprinted in [11].

20. Rosen, Sherwin. "Human Capital: A Survey of Empirical Research". In Ronald C. Ehrenberg (ed.), Research in Labour Economics: An Annual Compilation of Research. Vol. 1. Greenwhich, Conn.: JAI Press. 1977. pp. 3-39.

21. Schultz, Theodore W. "Capital Formation by Education". Journal of Political Economy. Vol. 68. November-December 1960. pp. 571-583.
22. Schultz, Theodore W. "Investment in Human Capital". American Economic Review. Vol. 51. March 1961. pp. 1-17.

23. Smith, Adam. An Inquiry into the Nature and Causes of the Wealth of Nations. London. 1776 (First edition). London: George Routledge \& Sons. 1903. pp. 78-79.

24. Walsh, John Raymond. "Capital Concept Applied to Man". Quarterly Journal of Economics. Vol. 49. February 1935. pp. 255-285. 